\title{
Physiological development of zygotic embryos of heliconias propagated in vitro and conventionally
}

\author{
Cláudia Ulisses $^{1}$; Marciana Morais ${ }^{2}$; Marta R Barbosa ${ }^{1}$; Cynthia C Albuquerque²; Lilia Willadino1; Terezinha \\ R Camara ${ }^{1}$
}

${ }^{1}$ Universidade Federal Rural de Pernambuco (UFRPE), Recife-PE, Brazil; claulisses@gmail.com (corresponding author); martaribeiro21@ hotmail.com; willadino.lilia@gmail.com; teca.camara@gmail.com; ${ }^{2}$ Universidade do Estado do Rio Grande do Norte (UERN), MossoróRN, Brazil; marciana.bio@gmail.com; cycavalcanti@gmail.com

\begin{abstract}
The aim of this study is to compare physiological development of Heliconia bihai cv. Lobster Claw Two plants derived from in vitro culture of zygotic embryos and conventional propagation. Heliconias obtained from rhizomes and from in vitro multiplication were evaluated every 30 days during ten months under greenhouse conditions. The experimental design was completely randomized, with ten repetitions, and the $2 \times 10$ factorial arrangement consisted of two plant multiplication methods and ten evaluations performed at different times. The analyzed biometric parameters were plant height, number of leaves, number of tillers, leaf area, and color intensity in the bracts. Plants derived from in vitro culture showed significant differences in the development of the evaluated physiological parameters in comparison to plants derived from rhizomes, and they also showed early flowering. Although the in vitro cultured plants were derived from zygotic embryos, no morphological changes were found in the vegetative and reproductive parts (inflorescence) of the plants or in the colorimetry. It shows that the in vitro cultures of zygotic embryos may be used as a technique to produce seedlings on a large-scale, thus allowing the floriculture sector to grow in the region and all over the country.
\end{abstract}

Keywords: Heliconia bihai, micropropagation, rhizome, vegetative propagation.

\section{RESUMO}

Desenvolvimento fisiológico de embriões zigóticos de heliconias propagados por cultura in vitro e convencionalmente

O objetivo deste trabalho foi comparar o desenvolvimento fisiológico em casa de vegetação de plantas de Heliconia bihai cv. Lobster Claw Two provenientes do cultivo in vitro de embriões zigóticos e de propagação convencional. Para tanto, helicônias obtidas a partir de rizomas e de multiplicação in vitro foram avaliadas a cada 30 dias durante dez meses. O delineamento experimental utilizado foi inteiramente casualizado, com dez repetições, sendo o arranjo fatorial 2x10, composto por 2 condições de cultivo e dez avaliações em tempos distintos. Os parâmetros biométricos analisados foram: altura da planta, número de folhas, de perfilhos, área foliar e posteriormente intensidade da cor das brácteas. As plantas obtidas do cultivo in vitro apresentaram diferença significativa no desenvolvimento dos parâmetros fisiológicos avaliados em comparação com as plantas provenientes de rizoma, como também, apresentaram precocidade na floração. Apesar das plantas provenientes do cultivo in vitro procederem de embrião zigótico, não foram observadas alterações morfológicas na parte vegetativa e reprodutiva (inflorescências) das plantas e nem na colorimetria, evidenciando que a técnica de cultivo in vitro de embriões zigóticos, pode ser utilizada para produção de mudas em larga escala, possibilitando incremento no setor da floricultura na região e no país.

Palavras-chave: Heliconia bihai, micropropagação, rizoma, propagação vegetativa.

Received on December 20, 2016; accepted on December 15, 2017

$\mathrm{T}$ he cultivation of ornamental plants has been constantly expanding and standing out in the national agribusiness, especially in the states of the Brazilian Northeastern and Northern regions (Farias et al., 2013). Besides aggregating high potential for future expansion, it also represents one of the main activities generating employment and income for micro and small producers across the country (Junqueira \& Peetz, 2014).

In order to reduce the negative impacts of the economic crisis on the international markets since 2008, the Brazilian floriculture sector is mainly focused on the domestic consumption to which it directs $96.5 \%$ of its production. Thus, the flower production chain moved R $\$ 5.22$ billion in 2013, and it grew over $38 \%$ in comparison to 2012. This result is considered to be positive against the economic growth prone to stagnation (Junqueira \& Peetz, 2014).

The country has many native or introduced species that fit the benchmarks and, in this scenario, heliconias stand out mainly for their beauty and rusticity (Albuquerque et al., 2014).

The genus Heliconia encompasses a wide diversity of ornamental plant species, varieties, hybrids and cultivars. The number of existing species is uncertain, but it comprises between 150 and 250 species. Approximately 40 species occur naturally in Brazil 
being known by several common names (Castro et al., 2007; Nascimento et al., 2014).

Heliconias may be conventionally propagated from rhizomes. However, this vegetative propagation system presents serious risks of spreading pests and diseases that may compromise the production and, consequently, marketing of the final product (Santos et al., 2006). Thus, the absence of phytosanitary-quality seedlings may compromise the production of heliconia seedlings by conventional methods.

Thus, the in vitro propagation is an alternative to produce heliconia seedlings with high physiological quality standard and free from diseases, fact that satisfactorily enables the economic development of such cultivation. The in vitro culture allows producing plants throughout the year regardless of weather conditions. In addition, it allows early and uniform flowering, thus enabling reducing the harvest period of higher yields (Álvares \& Caldas, 2002). Although there are no published scientific reports on the physiological and productive development of heliconias derived from in vitro culture, micropropagated seedlings may usually be more productive than conventional ones (Drew \& Smith, 1990).

Therefore, the aim of the current study is to compare the physiological development of $H$. bihai cv. Lobster Claw Two plants derived from in vitro culture of zygotic embryos and from conventional propagation (rhizome) in greenhouse.

\section{MATERIAL AND METHODS}

\section{Plant material}

H. bihai cv. Lobster Claw Two plants derived from in vitro culture of zygotic embryos measuring approximately $5 \mathrm{~cm}$ were acclimatized in $250 \mathrm{~mL}$ pots containing commercial substrate (Golden Mix). These plants were kept in greenhouse during 60 days at Rural Federal University of Pernambuco (UFRPE), under controlled temperature and light conditions. Plants were daily irrigated and received nutrient solution containing $742.86 \mathrm{mg} \mathrm{L}^{-1}$ soluble fertilizer every fifteen days (Kristalon,
3\% N; 11\% P2O5; 38\% K2O; 4\% $\mathrm{MgO} ; 11 \% \mathrm{~S} ; 0.025 \% \mathrm{~B} ; 0.004 \%$ Mo; 0.01\% Cu-EDTA; 0.025\% ZnEDTA; $0.07 \%$ Fe-EDTA and 0.04\% Mn-EDTA) and $840 \mathrm{mg} \mathrm{L}^{-1}$ calcium nitrate (BarcoViking, 15.5\% $\mathrm{N}$ and 19\% Ca).

After acclimatization period (60 days), plants were transferred to the

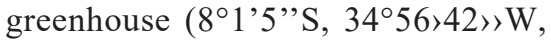
$6.4 \mathrm{~m}$ altitude). Plants were planted in substrate composed by washed sand, coconut powder and sugarcane filter cake (sugar-ethanol industry residue derived from juice extracted from the mills in the rotary filter) as substrate, at the ratio of $2 \times 1 \times 1$. The same procedure was performed in a 15-cm long conventional propagation unit (rhizome and pseudostem) derived from a commercial plantation in Paulista (07056'27' 'S, 34 ${ }^{\circ} 52^{\prime} 23^{\prime}$ 'W, $13 \mathrm{~m}$ altitude), Pernambuco State, Brazil. Irrigation was performed on alternate days, and each plant received $200 \mathrm{~mL}$ of nutrient solution every 15 days.

Evaluation of biometric parameters of the plants

During the experimental period (10 months), the following biometric parameters of plants were evaluated every 30 days: plant height (from the neck to the curvature of the fully expanded youngest leaf), number of leaves, number of tillers, and leaf area (all the leaves of the evaluated plants were measured). Leaf area (LA) was calculated according to methodology of Moreira (1987) based on the following formula: $\mathrm{LA}=\mathrm{LCW} \times \mathrm{LML} \times 0.8$, wherein LCW $=$ leaf central width and $\mathrm{LML}=$ leaf midrib length.

\section{Statistical analysis of biometric parameters}

The experiment was distributed in a completely randomized design with 10 repetitions. Treatments were distributed in a $2 \times 10$ factorial arrangement consisting of two plant multiplication methods, characterized by plants derived from in vitro culture of zygotic embryos and from conventional vegetative cultivation (VC) and ten evaluations performed at different times $(30,60,90,120,150,180,210,240,270$ and 300 days). Data were analyzed using statistical software (SISVAR, v. 4.0) and subjected to analysis of variance. The treatment means were compared using the Student's t-test $(\mathrm{P}<0.05)$ for the methods of plant multiplication factor. The variables evaluated according to the cultivation time were analyzed by regression, and the adjustment degree of the models was evaluated by coefficient of determination and by the significance of regression coefficients using t-test $(\mathrm{P}<0.05)$. Pearson's correlations were performed in pairs at $5 \%$ significance level in order to analyze relationship between the variables. The number of leaves, tillers and leaf area variables were normalized by transformation, before the analysis of variance. Flower stems were harvested to determine bracts color. They were cut $20 \mathrm{~cm}$ above ground and placed in 10-liter capacity containers containing 2.5 liters of distilled water where they were kept during 15 days.

\section{Analysis of color intensity of the bracts}

Color intensity was measured every three days using four replications. Bracts color was determined using a colorimeter (Konica Minolta Sensing, Inc.) operating in the CIE Lab system. Color measurement was performed with the sensor on the last inflorescence bract base surface (closed bract), based on the methodology proposed by McGuire (1992) and He et al. (2011). The following data were collected: $\mathrm{L}^{*}$, lightness, representing interval between black and white; $\mathrm{a}^{*}$, interval between green (-) and red (+); and $\mathrm{b}^{*}$, interval between blue (-) and yellow (+). Data were subjected to analysis of variance (ANOVA) and means were compared by Student's t-test $(\mathrm{P}<0.05)$, using the statistical software (SISVAR, v. 4.0).

\section{RESULTS AND DISCUSSION}

Throughout the evaluation period (10 months) we observed that plants derived from in vitro culture showed better vegetative growth than those grown from rhizomes (Figure 1A, 1B). Micropropagated plants may 
have advantages in comparison to the conventional propagation units, namely: faster establishment, early shoot emission, higher production and vigor during growth (Drew \& Smith, 1990; Teixeira \& Bettiol Neto, 2011). In addition, they may produce approximately $30 \%$ more in the first cycles and allow synchronized harvests due to seedling homogeneity (Sanada, 1993).

Plant height increased up to the $180^{\text {th }}$ day in both treatments and stopped at approximately 210 days, when plants were 1 meter tall. Plant height remained until the end of the experiment (300 days) (Figure 2A), which may be related to the space limitation in the pots. These plants usually reach 2 to 3 meters tall, but plants grown in containers frequently have limited space to grow their roots (Kämpf, 2000) and this root restriction can reduce plant height and leaf area (Leles et al., 1998). In addition, the container shape and size influence the water movement in the soil volume

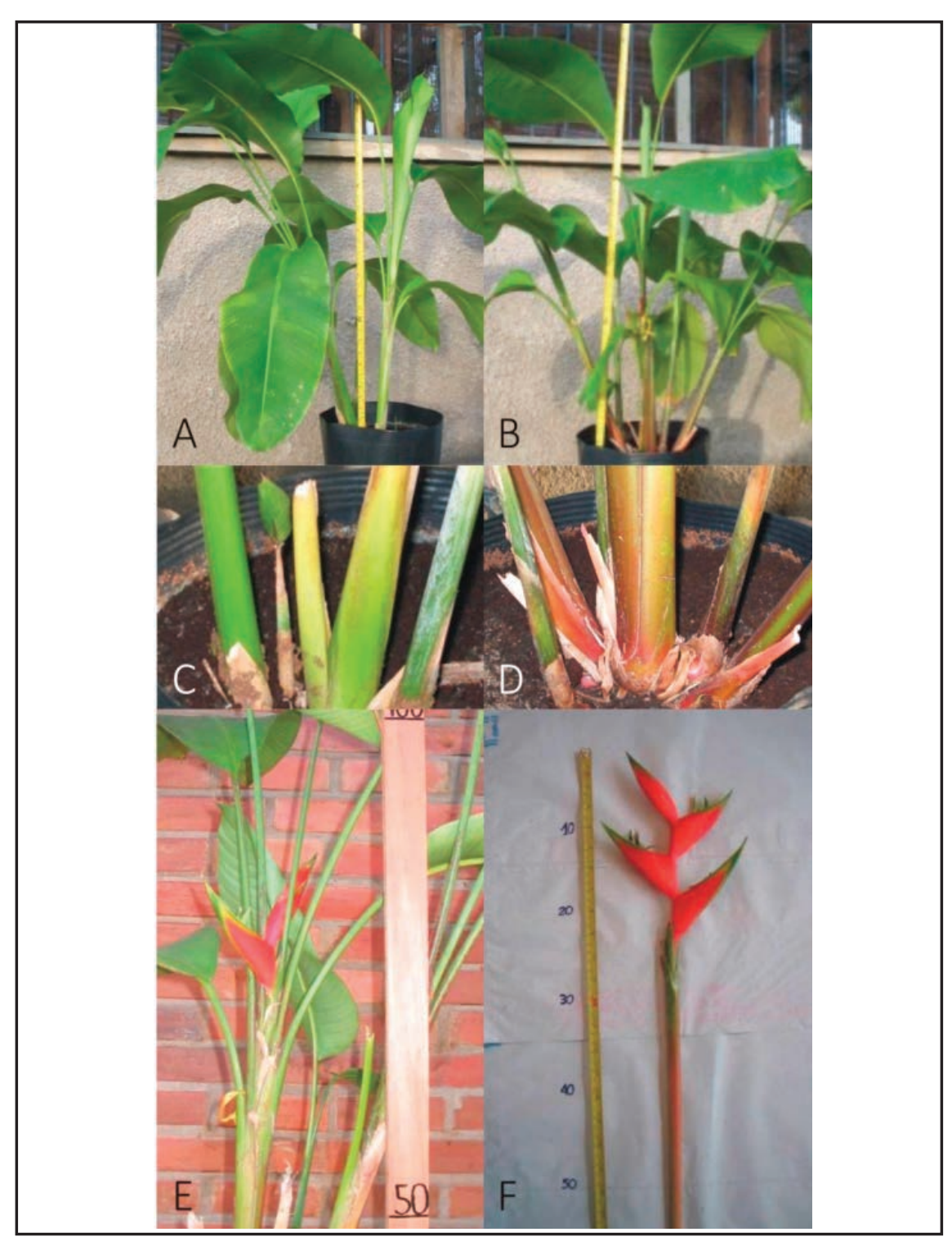

Figure 1. Development of H. bihai $c$. Lobster Claw Two plants in the greenhouse: rhizomederived plants at 240 days in the experiment (A) and plant derived from the in vitro cultivation of zygotic embryos (B); Pseudostem of rhizome-derived plant (C) and of plant derived from the in vitro cultivation of zygotic embryos at 240 days into the experiment (D); Inflorescence obtained in the plant derived from the in vitro cultivation of zygotic embryos at 279 days into the experiment (E); Inflorescence at harvest point at 291 days into the experiment (F). (Photos by Ulysses, C.). Recife, UFRPE, 2014
(Kämpf, 2000; Vallone et al., 2010).

The positive correlation between number of tillers and plant height $\left(0.95^{* *}\right)$ in plants derived from in vitro culture (Figure 2B) indicates that, in general, the plants producing many tillers show faster clump expansion. These results are consistent with those obtained by Rodrigues et al. (2006) who studied the same culture and observed the largest number of tillers as well as more flower stems in the treatment with micropropagated plants, which presented higher productivity in comparison to the conventional method. The number of tillers may actually help increasing the number of leaves and, therefore, lead to greater solar energy uptake, organic matter production and, consequently, to increased production of inflorescences (Assis et al., 2009).

There was significant difference among the treatments regarding number of leaves and leaf area. The difference in number of leaves started decreasing from the $150^{\text {th }}$ day on and that in leaf area started decreasing in the $180^{\text {th }}$ day (Figure 2C, 2D). Although the number of leaves is not always an appropriate criterion to estimate plant growth among heliconias, this variable has direct importance in the clump development and in flower stem quality, since the leaves are responsible for producing energy in plant due to their high photosynthetic efficiency (Albuquerque et al., 2010; Farias et al., 2013).

At approximately 250 days, the presence of a reduced-limbo leaf (flag leaf) was observed, preceding the inflorescence. According to Criley \& Broschat (1992), heliconia usually starts flowering after the plant reaches a considerable energy supply in order to start the reproduction process. The reproductive apex giving rise to the heliconia inflorescence is formed by the transformation of the terminal vegetative apex. This transition happens without external evidence until inflorescence becomes apparent.

Twenty percent $(20 \%)$ of plants derived from in vitro culture issued the inflorescence tip at the $266^{\text {th }}$ day ( 8 months and 13 days into the experiment). At the $275^{\text {th }}$ day, the first bract was already open (Figure 1E). The harvest 
Table 1. Colorimetry for deployment of the post-harvest time variable in each multiplication method of $H$. bihai cv. Lobster Claw Two. (Summary ANOVA). Recife, UFRPE, 2014.

\begin{tabular}{llll}
\hline Variation sources & GL & Fc value & Prob. $>$ Fc \\
\hline *L value & & & \\
\hline Post-harvest time & 5 & 1.232 & $0.3145 \mathrm{~ns}$ \\
Multiplication methods & 1 & 324.531 & $0.0000 * *$ \\
Post-harvest time x Cultivation types & 5 & 1.187 & $0.3347 \mathrm{~ns}$ \\
\hline *a value & & & \\
\hline Post-harvest time & 5 & 0.850 & $0.5236 \mathrm{~ns}$ \\
Multiplication methods & 1 & 338.901 & $0.0000 * *$ \\
Post-harvest time x Cultivation types & 5 & 0.809 & $0.5512 \mathrm{~ns}$ \\
\hline *b value & & & \\
\hline Post-harvest time & 5 & 0.551 & $0.7365 \mathrm{~ns}$ \\
Cultivation types & 1 & 94.000 & $0.0000 * *$ \\
Post-harvest time x Cultivation types & 5 & 0.411 & $0.8381 \mathrm{~ns}$ \\
\hline
\end{tabular}

point for the marketing ( 3 open bracts) of these inflorescences was achieved 25 days after inflorescence tip emergence. The obtained inflorescences showed mean size of $22.5 \mathrm{~cm}$ and the flower stems (inflorescence + stem) showed mean size of $55 \mathrm{~cm}$ (Figure 1F). Plants derived from rhizome propagation started issuing the inflorescence tip at the $310^{\text {th }}$ cultivation day. Inflorescences showed mean size of $24.7 \mathrm{~cm}$ and flower stem showed mean size of $58 \mathrm{~cm}$. Some authors (Drew \& Smith, 1990; Álvares \& Caldas, 2002) also observed that micropropagated banana plants flowered earlier than plants propagated by the conventional method.

Quality standard of flower stems

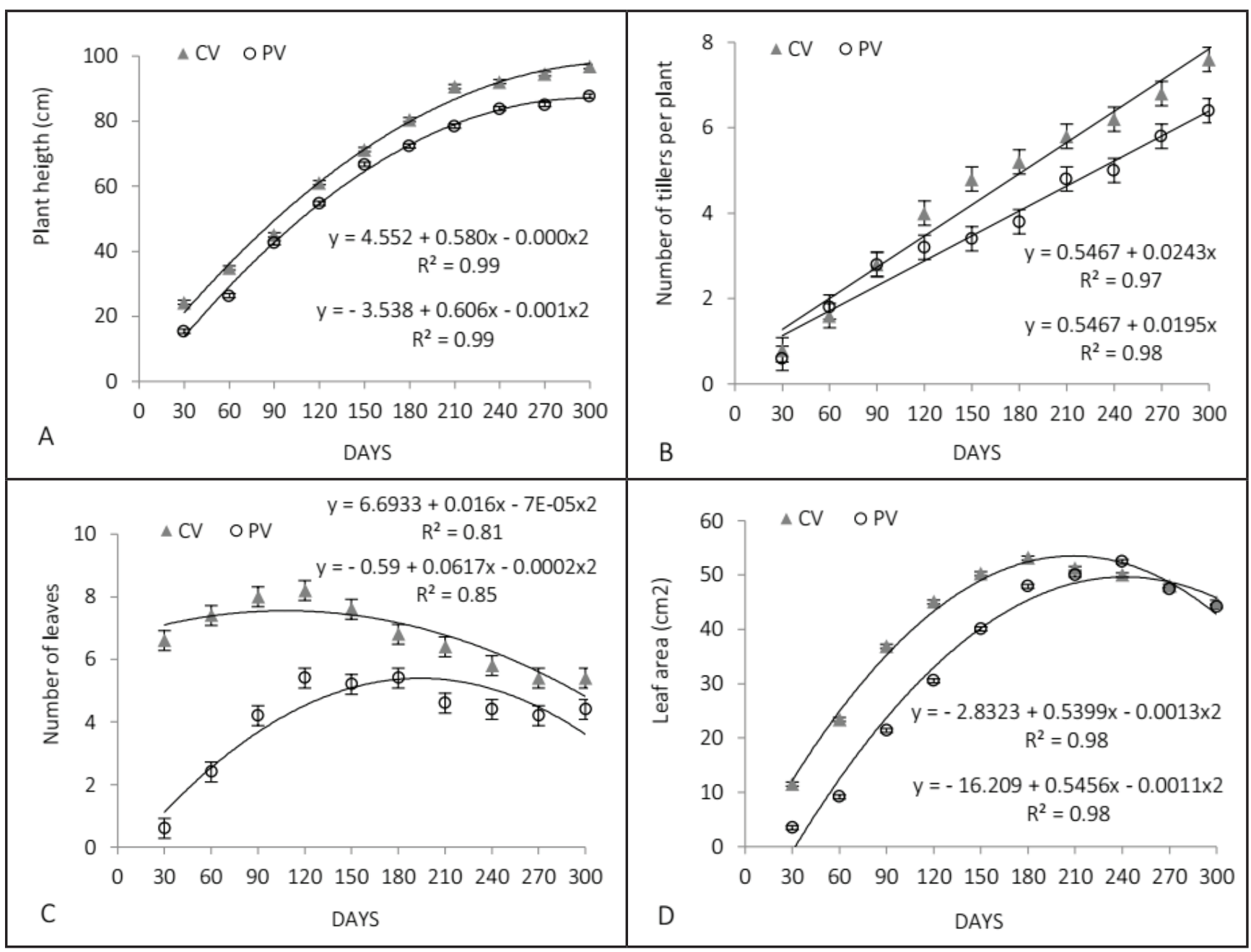

Figure 2. Biometric evaluation of Heliconia bihai cv. Lobster Claw Two plants according to cultivation time: $\mathrm{VC}=$ in vitro culture; $\mathrm{VP}=$ conventional vegetative propagation. Plant height (A), number of tillers (B), number of leaves (C), and leaf area (D). Standard error: A= $0.63563 ; \mathrm{B}=0.28460 ; \mathrm{C}=0.31780 ; \mathrm{D}=0.36804$. Recife, UFRPE, 2014. 


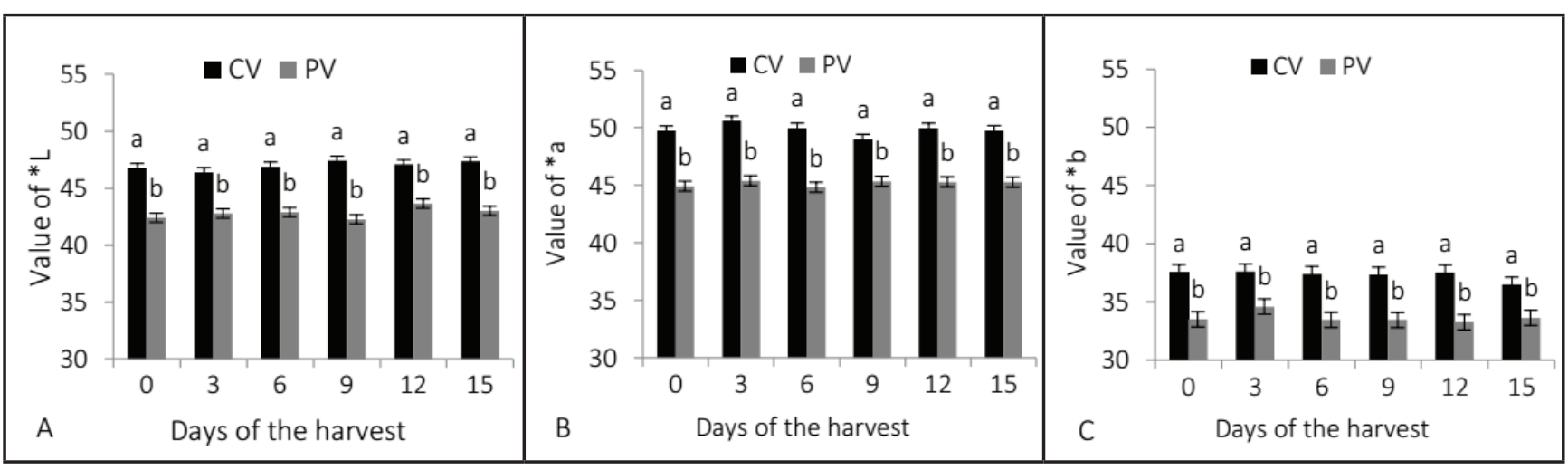

Figure 3. Colorimetry of Heliconia bihai cv. Lobster Claw Two plant preserved in distilled water 15 days after the harvest. L* (A), a* (B)* and $b^{*}(C)$ values. Equal letters do not statistically differ according to Student's t-test $\mathrm{P}<0.01$. OM $-\mathrm{VC}\left(\mathrm{L} *=46.9 ; *^{*}=49.8 ; * \mathrm{~b}=37.3\right)$, VP $\left(* \mathrm{~L}=42.8 ;{ }^{*} \mathrm{a}=45.2 ;{ }^{*} \mathrm{~b}=33.7\right)$. Standard error: ${ }^{*} \mathrm{~L}=0.39921 ; * \mathrm{a}=0.43813 ;{ }^{*} \mathrm{~b}=0.65560$. Recife, UFRPE, 2014.

is very appreciated by producers, since the stem is the final product. Thus, the greatest vigor observed in heliconias derived from in vitro culture may be linked to phytosanitary status of seedlings, which reflects the quality of these plants and may justify productivity gains (Álvares \& Caldas, 2002). The highest number of inflorescences and early flowerings represent lower production costs, greater competitiveness, more marketable products and, hence, higher profitability (Albuquerque et al., 2010; Paulino, 2013). In addition, regarding the production process, precocity means opportunity for the producer to put the product on the market earlier, to anticipate the return of investment as well as to increase the flower productivity per area and per production period (Farias et al., 2013).

About color intensity in the bracts, we observed that $L^{*}$, $a^{*}$ and $b^{*}$ values were not affected over time during the 15 post-harvest days, since no significant difference was found in the post-harvest time factor according to the $\mathrm{F}$ test, as observed in the analysis of variance (Table 1). In addition, no significant difference was found in the interaction between factors. Similar results were obtained by Costa et al. (2011) evaluating storage conditions of Heliconia bihai cv. Lobster Claw Two. The authors observed that color of bracts was not affected by storage time. However, it did not occur with the multiplication methods, which showed highly significant difference in the same test.

The overall means $(\mathrm{OM})$ observed for $\mathrm{L}^{*}$ were $42.8(\mathrm{VP})$ and 46.9 (VC), showing intermediate shade between light and dark. Regarding a*, the observed values were 49.9 (VP) and 45.19 (VC), thus indicating high red color intensity. For $b^{*}$, means were 33.6 (VP) and 37.2 (VC), showing slight tendency to yellow shade. Higher L*, $* a$ and $* b$ values were observed in the colorimetry of plants derived from in vitro culture in comparison to those derived from vegetative propagation. It indicated that plants derived from in vitro culture showed more intense color (Figure 3). Although there was bract senescence, occurring in the form of dry tips, rather than in the form of color change. It was considered to be positive because tissue discoloration is undesirable, since color is one of the most used parameters after harvest and it is also the most attractive quality attribute to consumers (Kays, 1991).

These results allow inferring about the good growth and development of plants derived from in vitro culture, which showed higher development in all evaluated parameters when they were compared to plants derived from rhizome propagation. It showed that the in vitro method induced higher vegetative and reproductive growth. Similar results regarding plant vigor, derived from in vitro culture, were observed in other studies (Teixeira \& Bettiol Neto, 2011; Rodrigues et al., 2014). Seedlings derived from micropropagation showed active root system and physiologically efficient leaf area from the time they were planted, fact that may justify the best initial plant performance (Drew \& Smith, 1990).

Although plants derived from in vitro culture came from zygotic embryos, no changes were observed in the external morphology of the vegetative parts (pseudostem and leaves) or in the obtained inflorescences. Therefore, zygotic embryos could be used as an explant source to enable in vitro multiplication of this heliconia species.

In view of this, it is concluded that H. bihai cv. Lobster Claw Two plants derived from in vitro culture of zygotic embryos showed higher vegetative growth in all evaluated parameters, in comparison to the rhizome-derived plants. In addition, they did not show morphological changes in the vegetative and reproductive structures. Color intensity in the bracts was not affected during the 15-day-post-harvest period in the evaluated propagation methods and showed early flowering, and the first flowering showed small reduction in the reproductive structures size in comparison to that of rhizome-derived plants.

\section{REFERENCES}

ÁlVARES, MC; CALDAS, LS. 2002. Crescimento, produção e variação somaclonal em bananeiras micropropagadas. Pesquisa Agropecuária Brasileira 37: 415-420.

ALBUQUERQUE, AW; ROCHA, ES; COSTA, JPV; FARIA, AP; BASTOS, AL. 2010. Produção de helicônia Golden Torch influenciada pela adubação mineral e orgânica. 
Revista Brasileira de Engenharia Agrícola e Ambiental 14: 1052-1058.

ALBUQUERQUE, AW; SANTOS, JM; FARIAS, AP. 2014. Produtividade e qualidade póscolheita de Heliconia "Golden Torch" submetida a fontes e doses de silício. Revista Brasileira de Engenharia Agrícola e Ambiental 18: 173-179.

ASSIS, AM; FARIA, RT; UNEMOTO, LK; COLOMBO, LA; LONE, AB. 2009. Aclimatização de bastão-do-imperador (Etlingera elatior) em substratos à base de coco. Acta Scientiarum 31: 43-4.

CASTRO, CEF; MAY, A; GONÇALVES, C. 2007. Atualização da nomenclatura de espécies do gênero Heliconia (Heliconiaceae). Revista Brasileira de Horticultura Ornamental 13: 38-62.

CRILEY, RA; BROSCHAT, TK. 1992. Heliconia: botany and horticulture of a new floral crop. Horticultural Reviews 14: 1-55.

COSTA, AS; NOGUEIRA, LC; SANTOS, VF; CAMARA, TR; LOGES, V; WILLADINO, L. 2011. Storage of cut Heliconia bihai (L.) cv. Lobster Claw flowers at low temperatures. Revista Brasileira de Engenharia Agrícola e Ambiental 15: 966-972.

DREW, RA; SMITH, MK. 1990. Field evaluation of tissue-culture bananas in SouthEastern Queensland. Australian Journal of Experimental Agriculture 30: 569-574.

FARIAS, AP; ALBUQUERQUE, AW; MOURA FILHO, G; REIS, LS. 2013. Produtividade da Heliconia psittacorum x Heliconia spathocircinata cv. Golden Torch sob diferentes fontes de adubação orgânica. Revista Brasileira de Engenharia Agrícola e
Ambiental 17: 713-720.

HE, Q; SHEN, Y; WANG, M; HUANG, M; YANG, R; ZHU, S; WANG, L; XU, Y; WU, R. 2011. Natural variation in petal color in Lycoris longituba revealed by anthocyanin components. Plos One 6: 1-8.

JUNQUEIRA, AH; PEETZ, MS. 2014. O setor produtivo de flores e plantas ornamentais do Brasil, no período de 2008 a 2013: atualizações, balanços e perspectivas. Revista Brasileira de Horticultura Ornamental 20: 115-120.

KAYS, SJ. 1991. Postharvest physiology of perishable plant products. New York: An Avi Book. 532p.

KÄMPF, AN. 2000. Produção comercial de plantas ornamentais. Guaiba: Agropecuária. $254 \mathrm{p}$.

LELES, PSS; CARNEIROM, JGA; BARROSO, DG. 1998. Comportamento de mudas de Hymanea courbaril L. var stilbocarpa (Hayne) Lee et Langenh. E Apuleia leiocarpa (Vog.) Macbr, produzidas sob três regimes de irrigação. Revista Árvore 22: 11-19.

MCGUIRE, RG. 1992. Reporting of objective color measurements. HortScience 27: 12541255.

MOREIRA, RS. 1987. Banana: Teoria e Prática de Cultivo. Campinas: Fundação Cargil. 335p.

NASCIMENTO, HR; GALLO, R; KARSBURG, IV; OLIVEIRA, AS. 2014. Cytogenetic and identification of the nucleolus organizer region in Heliconia bihai (L.) L. Revista Ceres 61: 451-457.

PAULINO, AS; ALBUQUERQUE, AW; MOURA FILHO, G; PEREIRA, FRS. 2013. Helicônia "Golden Torch": Produtividade e qualidade pós-colheita sob diferentes fontes e doses de silício. Revista Brasileira de Engenharia Agrícola e Ambiental 17: 615-621.

RODRIGUES, PHV; AMBROSANO, GMB; LIMA, AMLP; MENDES, BMJ. RODRIGUEZ, APM. 2006. Heliconia bihai var. Lobster Claw I: cut flower field production from micropropagated- versus rhizome-derived plants. In: SILVA, JAT (eds). Floriculture, ornamental and plant biotechnology: advances and topical issues. Londres: Global Science Books. p. 558-560.

RODRIGUES, PHV; BORDIGNON, SR; AMBROSANO, GMB. 2014. Desempenho horticultural de plantas propagadas in vitro de Sacha inchi. Ciência Rural 44: 1050-1053.

SANTOS, MRA; TIMBÓ, ALO; CARVALHO, ACPP; MORAIS, JPS. 2006. Estudo de adubos e substratos orgânicos no desenvolvimento de mudas micropropagadas de helicônia. Horticultura Brasileira 24: 273-278.

SANADA, M. 1993. Micropropagation of semitropical crop and its application to cultivation in Okinawa. In: THIQUYNH, N; UYEN, NV (eds). Adapted propagation techniques for commercial corps of the tropics. Stocjholm. p. 101-105.

TEIXEIRA, LAJ; BETTIOL NETO, JE. 2011. Comportamento agronômico de bananeira 'Prata Anã em função do tipo de muda. Revista Brasileira de Fruticultura 33: 89-95.

VALLONE, HS; GUIMARÃES, RJ; MENDES, ANG; SOUZA, CAS; CUNHA, RL; DIAS, FP. 2010. Diferentes recipientes e substratos na produção de mudas de cafeeiros. Ciência e Agrotecnologia 34: 55-60.C.). 